Abstracta Iranica Abstracta Iranica

Revue bibliographique pour le domaine irano-aryen

Volume 29 | 2008

Comptes rendus des publications de 2006

\title{
Iran, un monde en mouvement. Numéro spécial de la revue ParAgeS. Paris, Magellan \& Cie, 2005, 159 p., ill. photos coul. et N\&B.
}

Poupak Rafii Nejad

\section{OpenEdition}

1 Journals

\section{Édition électronique}

URL : http://journals.openedition.org/abstractairanica/23612

DOI : 10.4000/abstractairanica.23612

ISSN : 1961-960X

Éditeur :

CNRS (UMR 7528 Mondes iraniens et indiens), Éditions de l'IFRI

\section{Édition imprimée}

Date de publication : 15 mai 2008

ISSN : 0240-8910

Référence électronique

Poupak Rafii Nejad, «Iran, un monde en mouvement. Numéro spécial de la revue ParAgeS. Paris,

Magellan \& Cie, 2005, 159 p., ill. photos coul. et N\&B. », Abstracta Iranica [En ligne], Volume 29 | 2008,

document 10, mis en ligne le 15 septembre 2008, consulté le 26 septembre 2020. URL : http://

journals.openedition.org/abstractairanica/23612; DOI : https://doi.org/10.4000/abstractairanica.

23612

Ce document a été généré automatiquement le 26 septembre 2020.

Tous droits réservés 


\title{
Iran, un monde en mouvement.
} Numéro spécial de la revue ParAgeS. Paris, Magellan \& Cie, 2005, 159 p., ill. photos coul. et N\&B.

\author{
Poupak Rafii Nejad
}

Consacré à l'Iran, ce numéro spécial de la revue ParAgeS (revue littéraire fondée en mai 2000 par des élèves de l'École normale supérieure de Paris) est en quelque sorte le résultat et le prolongement de la première semaine iranienne organisée à l'ENS (14-18 avril 2003) et dont le but était de présenter une autre image de l'Iran par rapport à celle proposée dans les médias. Par sa mise en page ludique avec les illustrations de Marjane Satrapi, l'ouvrage est destiné à tout public mais avec un contenu riche et intéressant. Autour de quatre axes principaux (Poésie, Art, Critique et Notes et Notules) il contient la traduction de quelques vers de Mowlānā et de Hayyām, un article de Ch.-H. de Fouchécour sur Ḥāfez intitulé « Hafez à la cour de Perse », et d'autres articles critiques tels que «Les racines du cinéma iranien » par Farrokh Gaffary, «État et société civile dans le monde iranien " par Nouchine Yavari d'Hellencourt, "L'Avesta et la figure de Zoroastre » par J. Kellens, « Nietzsche contre son étoile d'or » par Maël Renouard, «Autour du jardin persan » par Gérard Granval, etc.

\section{INDEX}

Thèmes : 1.2. Recueils d'articles : revues, colloques, ouvrages collectifs 


\section{AUTEURS}

POUPAK RAFII NEJAD

CNRS - Mondes iranien et indien - Paris 